\title{
OPORTUNIDADES AGROINDUSTRIALES EN LA CUENCA DEL PACÍFICO
}

\author{
William C. Bailey \\ Lidia V. Norina \\ MASSEY UNIVERSITY \\ Palmerston North, Nueva Zelanda
}

$\mathrm{E}$ $S$ interesante que dos países tan distantes entre si, Perú y Nueva Zelanda, sean similares en muchos aspectos. Por ejemplo, la agricultura es muy importante para ambos. En Nueva Zelanda el $14,6 \%$ del Producto Bruto Interno está relacionado con la agricultura (ver Cuadro 1). Una gran ciudad domina en ambos países: en Nueva Zelanda, Auckland concentra un tercio de la población; en el Perú, Lima alberga a la quinta parte de toda la población. De hecho, hay más gente en Lima que en toda Nueva Zelanda. La geografía también es importante para ambos países. Nueva Zelanda está formada por dos islas: la Isla Norte es exuberante y verde, casi tropical, mientras que la Isla Sur es montañosa y accidentada. En el Perú se distinguen tres y no dos áreas geográficas principales: la costa, la sierra y la selva. Algunas partes de la Isla Sur son parecidas a la sierra, y la mayoría de Nueva Zelanda se parece a la región costera. En cambio, no tenemos nada parecido a la selva.
Al igual que al Perú, la geografía ha dado a Nueva Zelanda ventajas comparativas para producir algunos bienes -productos lácteos, lana, algunos productos cárnicos, algunas frutas y verduras-. Naturalmente, estos productos constituyen exportaciones muy significativas para Nueva Zelanda. La geografía también ha hecho posible que el Perú sea reconocido internacionalmente como productor de harina de pescado, merluza congelada, verduras, como el espárrago y el brócoli, y frutas, como el mango.

En la Figura $I$ se detalla el significado que tiene la exportación de ciertos productos para Nueva Zelanda. Evidentemente, el valor de estas exportaciones varía según el producto, desde los 143 millones de dólares de las exportaciones de venado hasta los 3.792 millones de dólares de las exportaciones lecheras. Sin embargo, la importancia de los mercados ultramarinos para estos bienes es notable y explica la razón que sustenta la atención que pone 
Cervena se puede originar sólo en Nueva Zelanda, Zespri, la nueva marca del Consejo de Comercialización del Kiwi, se aplica sólo al kiwi de Nueva Zelanda. Queda por verse si el kiwi neozelandés, independientemente del nombre, tiene características que efectivamente lo diferencien de los otros kiwi y le permitan cobrar un precio más alto. Como se indica en la Figura 9, se prevé que esta estrategia evitará, en el mejor de los casos, mayores descensos en la producción y en el retorno para los agricultores del sector.

\section{La concentración en el cliente}

El punto central para aprovechar los retos $y$ oportunidades en la agroindustria es no olvidar nunca la importancia del consumidor. Los patrones de consumo están cambiando y la importancia otorgada a productos sensibles al medio ambiente, frescos y saludables está creciendo. Esto significa que las empresas y los países que eligen concentrarse en productos de valor agregado en vez de materias primas se están volviendo cada vez más importantes y rentables. Pero es más fácil recordar los viejos tiempos que planear para el futuro.

Los exportadores de Nueva Zelanda sacan ventaja de la imagen que muchos consumidores tienen sobre Nueva Zelanda como un país limpio y verde. Por ejemplo, la publicidad del Consejo Lechero de Nueva Zelanda para sus ventas en Rusia muestra escenas de pastos verdes y montañas cubiertas de nieve, que son muy típicas de Nueva Zelanda. Está abierto al debate sobre cuánto tiempo más puedan ayudar estas imágenes y el concepto de "limpio y verde" a los exportadores. En el Japón, una investigación muy reciente indica que el concepto de "limpio y verde" no era un factor significativo en los motivos de compra de los consumidores. Más aún, la investigación señala un descenso en el interés de los japoneses por las frutas y verduras frescas. Esta demanda se estaba reemplazando por la de productos congelados o procesados. La investigación concluye que el Japón se estaba haciendo un mercado mucho menos atractivo para la fruta y verduras de Nueva Zelanda.

Un problema de la fuerza exportadora de la agricultura de Nueva Zelanda es la tendencia a olvidarse de los clientes nacionales. Muchos bienes producidos en Nueva Zelanda se venden en el pafs sólo porque no fueron de calidad suficientemente alta para la exportación. Algunos productos, como por ejemplo la mantequiIlla untable que vende el Consejo Lechero de Nueva Zelanda, requieren que el comprador neozelandés viaje a Europa a comprarla, porque no se vende en el país. El olvidar al cliente local concentrandose sólo en las exportaciones es una estrategia cuestionable, buena para el corto plazo quizá, pero no es sostenible en la industria alimentaria.

Nosotros, cuando pensamos en el Perú, pensamos en las limpias nieves de los Andes y en las selvas tropicales. El país contiene muchos tesoros, no sólo tesoros incas, sino tesoros únicos en plantas. La uña de gato, un producto que me era desconocido hasta hace poco, es un ejemplo. Este producto se publicita en la Internet $\mathrm{y}$, en consecuencia, está disponible para el mundo. El camu camu es otro que está ganando reputación internacional. La descripción que aparece en la página de Internet de la uña de gato es de lo más interesante: 
"La uña de gato es un recurso natural precioso y vital que se debe cosechar de una manera ecologicamente segu$\mathrm{ra}$."

"Como trabajamos directamente con los indios Ashaninka, podemos cosechar con las mismas prácticas 'de respeto a la tierra' que se han usado por siglos".

"No compramos nuestra materia prima, sino que la cosechamos directa. mente en la Amazonía peruana. Podemos pasarle nuestros ahorros a usted; no hay intermediarios".

Todas estas frases reflejan un enfoque hacia la sostenibilidad y el servicioal cliente que las compañías en Nueva Zelanda están empezando a adoptar. Para ambos países la cuestión es cómo mantener una ventaja competitiva con etiquetado de origen.

Mientras que sacar ventaja de nuestras dotes naturales es una buena estrategia de negocios, otra es desarrollar productos especificamente destinados al mercado de exportación. Ya he mencionado el éxito de la mantequilla untable. Otro ejemplo es la habilidad que tienen los cultivadores de flores para aprovechar la ubicación de Nueva Zelanda y vender en el hemisferio norte en contraestación. Cada año, los productores obtienen flores con nuevos colores y características que se colocan a precios altos en los mercados japoneses durante el invierno. Las flores tienden a establecer el estilo que las flores de otros países imitarán tanto por ser nuevas como por ser las primeras. Como Nueva Zelanda no tiene las ventajas comparativas del Perú para el cultivo de las flores - clima templado y proximidad razonable a los mer- cados-se reconocí la necesidad de usar la ciencia como ventaja. A través de la Internet está emergiendo un mercado de flores. Las ventas electrónicas de flores abren vastos y nuevos mercados para las flores únicas. Para países como Nueva Zelanda, pequeños pero con una reputación única en todo el mundo, la venta electrónica de flores es estimulante. $i \mathrm{C} 6$ mo comerciará su país con éxito la gipsophilia en todo el mundo?

Los clientes en todo el mundo están buscando frutas $\mathrm{y}$ verduras nuevas $\mathrm{y}$ no tradicionales. En un tiempo el kiwi era exótico. Hoy el productor más grande de kiwi en el mundo no es Nueva Zelanda, sino Italia. ¿Como será el próximo kiwi? Nuestros dos países se beneficiarian si se unieran para investigar los mercados para frutas y verduras exóticas. Sabemos poco sobre el camu camu, la chirimoya y la lúcuma, productos todos que se asocian estrechamente al Perú.

No hay un volumen significativo de comercio agrícola entre nuestros dos pafses. Nuestros plátanos vienen del Ecua. dor, muchos de nuestros mangos son de México. Quizá las exportaciones peruanas de frutas tropicales convendrian a los dos países. Un estudiante peruano graduado en la Universidad de Massey está estudiando la economía de la exportación de frutas exóticas del Perú a Nueva Zelan. da. Puede haber algunos asuntos fitosa. nitarios involucrados, pero primero se tie. ne que evaluar el costo de la exportacion de las frutas para saber si puede surgir un comercio rentable.

Nuestros países tienen una historia de investigación común. De 1974 a 1978 , hubo un extenso intercambio de cientifi$\cos$ entre nuestros dos países cuando in- 
vestigaron el mejoramiento de pasto $y$ ganado en el altiplano.

La protección del recurso natural es importante para nuestros dos países. Los conflictos entre usar nuestros recursos naturales y conservarlos son intensos. $\mathrm{La}$ investigación sobre cómo manejar nuestros recursos naturales y a la vez mantenernos competitivos en el mundo inter- nacional de la agroindustria beneficiaria a nuestros dos países.

Me he referido sólo a una pequeña área de negocios e investigaciones compartidos. Me complacería trabajar con ustedes estrechamente para investigar áreas adicionales de preocupación común para nuestros dos países. 